\title{
8. Yagan, Mrs Dance and Whiteness
}

\author{
Jan Idle
}

\section{Perth}

It is a very hot day in the northern suburbs of Perth, Western Australia; really hot and very dry. It is the kind of day when the shimmer of the temperature distorts the horizon line of the Indian Ocean that I can see when we go to swim. The beach is ten minutes walk from my parents' house, a 1970s dream home, originally with shag pile carpet, which has long been replaced. On days like this it is too hot to walk, and we drive for our mid-morning swim, the second swim of the day. The heat from the bitumen makes the air shimmer and the sand sears our feet, so we get as close to the sea as possible before running shoeless for the water and gentle waves. It is perfect weather for drying laundry, yesterday's dirty washing is white, pristine, folded and put away before lunch. It is Perth and this is Christmas. We return 'home' regularly to visit relatives and old friends, to reconnect with our shared history, but by the end of two weeks I am always ready to go back to the east coast, where my real life is disconnected from my Western Australian past, which is how I prefer it. Besides, all that swimming gives me water brain and all I can imagine is immersing myself in the salty water of the Indian Ocean in order to get cool, and I cannot think. The distance between there and here is geographically and psychically great, and 'home' pulls in both directions. That past continues to live into my present, hounding my academic endeavours, luring me into remembering history and acknowledging it.

When it is this hot, we go to the Karrinyup Shopping Centre, a 20-minute drive south, or to the Art Gallery of Western Australia, which takes about the same time but on the freeway, to enjoy the air-conditioning until the sea breeze, affectionately referred to as the 'Fremantle Doctor', comes in, offering some relief from the relentlessness of dry and hot. The shopping centre can be too crowded and too awful, claustrophobic, and you can be swallowed up by the consumerism of Christmas or the frenzy of the Boxing Day sales, or encounter fierce parking anger as the drivers try to park close to the entrance of the centre to minimise the transfer from air-conditioned car to air-conditioned shops and avoid the barren walk across the bitumen. A trip to the gallery is usually more 
pleasant, entertaining and diverse. No parking problems there and it gives us (that is, the extended family and me) something to talk about. But when it is this hot it is too hard to think.

The heat is nostalgic and familiar, pulling me back into this place, returning me to what I left behind. The sense of longing to belong and a conflicted connection with the past and its heritage persists in post-colonial, non-Indigenous Australia, and is acted out through a 'haunted community', a community haunted by the deaths of others (Secomb 2002, pp. 131-150), and 'white paranoia', the anxiety of white settlers' possession of territory (Hage 2003, pp. 47-66). It is a community that continues to negotiate: the history and lie of terra nullius, the 2008 apology to the Stolen Generation, the intervention into Indigenous communities in the Northern Territory, and the gap between Indigenous and non-Indigenous lives. Australian concepts of identity are underpinned by their complex relationships with the past, marked by 'discontinuity' where 'what we choose to call the past is reflexive: the past is not so much that which has already happened as it is a label to be applied to that which we wish to finish and forget, from which we wish to differentiate ourselves and thus to absolve ourselves from responsibility' (Rose 2004, p. 18). 'Many Aboriginal people in the Victoria River District ... indicated they believed Whitefellas were in a state of epistemological crisis ... [not knowing] what to remember and what to forget' (Rose 1997, p. 101). The promise of this amnesia, this archiving of memory, is that an Australian identity can be imagined and arise from a clean, working space with all the tools and the messy ingredients of colonising country and nation put away, neatly contained by labels and timeframes, and separate from us. That past is done, but not here in the gallery, here there is only respite from the heat (Connerton 2008, pp. 59-71).

Artefacts and visual culture display a form of institutionalised heritage, engaging us with what we can know or understand of the past. It prompts us to revisit and articulate the haunted community, whiteness, disconnection, and shame of the past and the present in the Australian context, bringing history into the everyday. I return to look at two paintings from the permanent collection in the Art Gallery of Western Australia. These paintings help me to think about the representations of shared (and contradictory) meanings of historic events through paying attention to a local, idiomatic and experiential or 'vernacular heritage', to engage with constructions of (my) identity and history (Healy 2008, p.105). One painting, of Mrs Dance, the boat captain's wife, and the other, of Yagan, a local Indigenous leader, illustrate historic events of Western Australia that took place in 1829 and 1833, approximately two to three kilometres from each other, a similar distance from where the gallery now stands. The foundation 
of Perth, Mrs Dance strikes the first cut August 12, 1829 was painted in 1929 by George Pitt Morison, former curator at the Western Australia Museum and Art Gallery, and Yagan (1833) was painted by contemporary Indigenous artist Julie Dowling in 2006. Completed long after the events they depict, these images form conversations between the histories that have made me and the history I make, conversations between the paintings and the events themselves and between a younger and older self (Muecke, this volume). Both paintings reflect the political climate at the time of their execution, flowing with the 'tides of remembering and forgetting', where 'one moment Aboriginality seems to be enormously significant and in the next, of historical interest only' (Healy 2008, p. 204). Here history is performed at the command of the painter, 'something like a script that is at one's command as an assignment', coming forward and returning elsewhere (Spivak 1989, p. 114).

\section{Painting}

Inside the cool gallery, memory returns. We have escaped from the sun and the shopping centre. I have been looking at and thinking about these pictures, Yagan and Mrs Dance, for some time and return to see them with my family. The one I am more familiar with, Mrs Dance, holds recollections of my naïve childhood understanding of the founding of the colony. My introduction to the events in the painting and Mrs Dance's story coincided with the feminist political climate of the early 1970s (Idle 2010, pp. 527-541). It answered simplistically the perplexing question of how I came to be here, it helped me feel at home, comfortable, settled, clear not confused, the transition from Aboriginal land to white settlement smooth and non-violent. Looking at the white woman courageously chopping down a tree, I belonged. The other picture of Yagan was painted almost 80 years later and challenges everything that was then so explicit and easily explained by the first. It disrupts the easy, unsophisticated understandings of colonial history depicted in Mrs Dance, and draws attention to an Indigenous narrative at a time when cultural institutions and their (white) audiences were ready to hear and see them. The paintings can be found not quite side-by-side but near to each other in a postcolonial display in the permanent collection. I am drawn to them both. Pitt Morison, painting at a time when white settlers were calling for the expulsion of Indigenous children from public schools, has, consciously or not, overlooked Indigenous presence and documents a moment in white colonial history (Haebich 2004, pp. 267-289). Dowling's picture reflects the political climate of remembering Indigenous presence and mimics a romantic narrative she describes as influenced by looking at Hogarth 
paintings. She portrays a story of an important Indigenous leader and defender of Indigenous land and culture, and her work is one of the many 'distinctive and strong Indigenous voice(s)' that have come to be celebrated in Australian cultural institutions in the flow of remembering Indigenous heritage that has become 'a catalyst for a re-evaluation of Australian history' (Perkins in Isaacs 2011, Introduction). Like Gordon Bennett and Daniel Boyd, Dowling's work provokes a political revisiting of Indigenous history in Australia. Dowling's imagery draws on historic narratives, diaries and oral history, while Boyd and Bennett rework well known colonial imagery 'answering back' to their (colonial) message (Nugent 2009).

Here in the cool gallery, I can think about painting and history, my history and that of the paintings and painters, Julie Dowling and Mrs Dance, George Pitt Morison and Yagan. Critic Ian Burn writes that a landscape 'is not something that you look at it is something you look through' (Stephen 2006, p. 220), and it makes sense. The labour of these images is in performing the public role of narrating the settler nation, telling stories of our colonial past back to us, interrupting our historical understanding and the present. Standing here looking, this past comes back shaped differently and always incomplete. This telling of history pushes me into thinking about Indigenous presence, then in the 1800s, in my childhood of the 1960s and 1970s, and now. Moving from country town to country town, I started school in a small wheat-belt town with lots of Indigenous kids and after three years we moved south to the coast, where it was whiter and even more English; it rained and the country was green. We moved again to a milling town, and then again. The nomadic nature of this childhood meant that any relationships were fleeting: Eric, who drowned in the pool aged seven; Jenny, who had the first colour TV in town; Heather, whose old English father drove a Rolls Royce, Nancy at the birthday party; and Hedley at the school gate teasing us as we walked across the road home to the headmaster's house. No Captain Cook here. He didn't fit into our colonial mythology. In Western Australia, our history was more Dutch, and our belonging transient. My focus was always on surviving the alienating climate of a new school, wondering how we came to be here and how long we would stay. Perceptions of colonialisation were constructed through fleeting glimpses of contradictory observations, pushed to the back of memory, pushed to the outside of town. In the public cultural institution of the art gallery, through the stories of Yagan and Mrs Dance, I am called to remember the habits of my forgetting and my will to remember (Healy 2008 , p. 35, 204), to pay attention to the shared and sometimes contradictory meanings of objects and images, a vernacular heritage. 


\section{Mrs Dance}

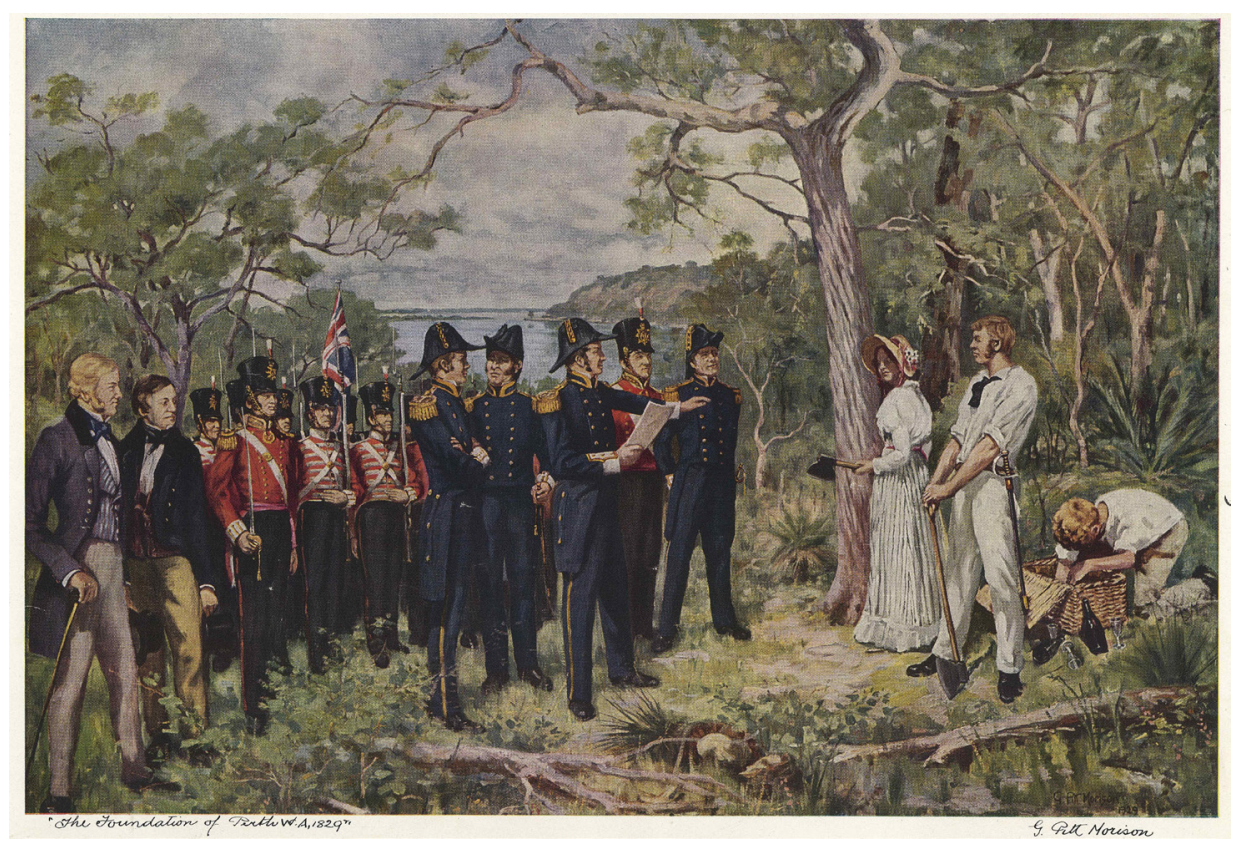

\section{'The Foundation of Perth, Mrs Dance strikes the first cut', George Pitt Morison (1929) Art Gallery of Western Australia.}

Source: National Library of Australia, nla.pic-an7748217.

In white people's history white women are mythologised as the brave woman who fought against the harsh climate, but no mention is made about how they lived and profited from the land stolen from Indigenous women. (Moreton-Robinson 2000, p. 174).

And here she is, Mrs Helena Dance, 1829, accompanied by Captains James Stirling, Charles Fremantle, Frederick Irwin, Mark Currie and William Dance, Peter Brown, Lieutenant J Septimus Roe and Dr William Milligan, as well as members of the 63 Regiment, and some of the crew from the HMS Challenger who travelled up river to mark the foundation of Perth. As recorded by Fremantle, 'there being no stone' to turn, Mrs Dance was enlisted to 'strike the first cut' into the felling of a tree (Cygnet 1935). The historic record shows that, within five years, at least two of these officiating white men, Stirling and Roe, would take part in the ambush and bloody massacre of Indigenous people in Pinjarra, south of Perth, in order that Thomas Peel could take up good farming land along the Murray River with impunity (Perth Gazette 1834, pp. 382-383; Fletcher 1984). Early in the morning on the Murray River it is cool, even if the day promises to 
be hot. The water keeps the heat down until slightly later in the day and it is a popular place for camping and canoeing, which I did as a teenager, only reading about Stirling, Roe, and the massacre later when I had moved to the other side of the continent. But here, in this painting, Stirling and Roe are on their best public behaviour, well-dressed and gentlemanly, this colonising project is ceremonial. Pitt Morison's painting was well received when it was donated and displayed in 1929. The scene is passive, despite the axe and the armed men. The process of colonisation is neat and nice, almost dull, the founding of Perth a matter of formal arrangement that neglected the original inhabitants. In 2012, Mrs Dance maintains her position in the gallery collection, holding a space for colonisation, neat in her bonnet, a solo white woman surrounded by Indigenous absence and men in ceremonial dress, braving the heat-fighting against the 'harsh climate'. She performs the task of white female icon, brave and visible; she made space for a white girl growing up in a masculine rural environment in Western Australia and connected my presence in the settler state with the past (Idle 2010). Following the sequicentenial celebrations of 1979, Janda Gooding wrote that this painting had 'come to be accepted as a true and accurate record of the past' (Gooding 1989, p. 115) and, in 2011, my friend Karen Fisher reported to me that the gallery guide still carefully described the scene as an 'authentic' reproduction of the event. Mrs Dance's story endures.

Whiteness is displayed and maintained as the base from which otherness is defined. Being non-Indigenous is not spoken, it is a given. Encountering Mrs Dance in my childhood as a representative of the colonising of the state in this somewhat mediocre but much reproduced image smoothed over the unsettling state of understanding colonialism. Mrs Dance stood in for the good, white woman, and she held the axe, she made up my past, neat and contained, and I imagined how I came to be here through what I mistook for feminist presence. Katrina Schlunke writes of 'an environment of systemic whiteness. "White" endures in a way that other categories or ways of knowing do not, but "white" is also a kind of silence written into how we know the past and how we see the land around us' (Schlunke 2005, p. 234). In the painting of Mrs Dance, this whiteness is performed through Indigenous absence. Moreton-Robinson writes: 'White women have privileges accorded them by their membership of the dominant group ... They have access to more resources, enjoy a better standard of living, earn more money and are better educated than Indigenous women' (Moreton-Robinson 2000, p. 174). This assumed privilege is reinforced by the position, place and reproduction of Pitt Morison's painting and I wonder if it will return, or come out again for the bicentennial of Perth in 2029.

In Bluff Rock: Autobiography of a massacre, Katrina Schlunke begins by describing how she had always 'known that Aboriginal people were killed as a part of the taking of land in Australia. I learnt this in New England, 
where I was born, as I learnt to walk. It seems it was never a shock' (Schlunke 2005, p. vi). Knowing is different from feeling, and Schlunke writes the story of the Bluff Rock massacre through retelling the past in her present and draws out how that past informs and is felt. Walking through the dense scrub and bush of Bluff Rock with her partner Susan, Schlunke recounts historic records of the massacre, wondering how the pursued Indigenous people were thrown off the top or jumped to their deaths; how could the horses scramble up those rocks? Her book disallows the present to be fleeting and moving into the future but stays still, embodying the history of place. This future is within the past via the present - the thick bush and sharp rocks. We are held by place and temporality is held in place, helping us to know what to remember. Her challenge to us is to feel history's breath, to feel, acknowledge and speak the violence of contact between settlers and Indigenous people in the colonising of Australia; history's breath into the writing of the white researcher and into the present. In the gallery, in front of Mrs Dance is the airless heat of white history.

Unlike Schlunke, who had always known of the settler-Indigenous conflicts, retribution sorties and massacres, on the other side of the continent, in Western Australia, this wasn't the case for me. I was not preoccupied with Indigenous presence, but with more self-centred concerns. Later, when I was listening more closely, I heard the stories of resistance and massacre. This is not to say that these were unspoken. The Indigenous absence from my family storytelling came from being cosseted in a white environment, sitting politely at the quiet dinner table, watching our manners. Indigenous presence was a part of school, but not home. Indigenous people were out there, beyond the edge of town. We had seen them as we drove across the Simpson and Great Sandy Deserts in 1969. We had artefacts: the carved wooden souvenirs from Docker River on the mantelpiece and the shield from cousin Clem's shed. Indigenous people were there but, as if by magic, not known. Not-knowing or asking was an affect of being good and a product of the political climate in our house. Ross Gibson writes: 'Knowing is an after-effect of understanding' (Gibson 2010, p. 4). This not-knowing is an after-effect of not-understanding, a part of Stanner's 'great Australian silence' (Stanner 1991). For me, in Western Australia the transition from Indigenous ownership and presence to white colonial possession and Indigenous absence was as straightforward as a white woman striking a blow at a native tree, everything else was unspoken. The painting held the narrative tightly in the myth of non-violent transition, reinforcing Indigenous invisibility from 'settler' view, hiding, what novelist Alexis Wright has called, 'stories too shameful to tell', haunting memories and frightening silences (Wright 2007).

Often when I am thinking about this past and memory, I call my mother. She quite likes a conversation, especially one that helps her to think. My childhood recollection of her is detached and distant, but she is a willing 
communicator these days. She will happily engage in a conversation about the past and takes seriously my interest in Mrs Dance and Yagan. Recently, she has been keen to discuss an exhibition of Indigenous painting from the travelling exhibition 'Yiwarra Kuju, the Canning Stock Route' (Davenport, La Fontaine \& Carty 2011), which she has been to see three times. She is struck by the story of the stock route's construction and the violence; she wants to talk about Indigenous perspectives.

This visual display has triggered different knowing and understanding for her, and our conversation leads me to ask about the Indigenous-settler relationships in the rural community of her childhood. A time marked by the brutal assimilationist policies of A. O. Neville, Chief Protector of Aborigines in Western Australia, who was key in 'shaping policy from 1915-1940' (Haebich 1988). So I draw up my courage: when she was growing up, did she know about the violence, the conflict? Sometimes these 'tricky' questions have not been well received; sometimes my tone and our relationship interferes with our conversation and, as she always has, she starts by replying to a different question: 'We hadn't even known how badly they bombed Darwin during the war.' (Her father was based in Darwin during World War Two.) She went on to say she was aware of racial conflict, and sometimes she and her sister would play with the Aboriginal kids, but at other times, fight. Sometimes this meant being prevented from using the bridge and they would wade through the river to get home from school. She tells me a story I hadn't heard previously - a 'story too shameful to tell' - of my great-great-grandmother, Grannie Norrish, wielding the shotgun on the verandah of the farm near Kojonup, Western Australia, to keep the Indigenous locals away from the water on the farm, our white advantage built on Indigenous deprivation (Moreton-Robinson 2000). I had wanted my history to be different from this shame, to keep an academic distance, but here it is, that past now into my present. Robyn Ferrell describes the impossibility of community in the Australian settler state as a product of the embodied shame of non-Indigenous people (Ferrell 2004, pp. 29-46). Memory and shame of the past is repeated in the boredom and shame of the present, and the collision of the will to remember and the longing to forget plays out in the shared space or shared heritage of community, alongside debates about who 'makes' or controls public memory (Healy 2008).

When I ask Mum if she knew about Yagan, she replied that she had only heard of him when vandals attacked the statue at Matagarup on Heirrison Island. It seems that neither of us remembers the children's story written by Mary Durack, The Courteous Savage: Yagan of Swan River (Durack 1964), which describes the relationships between Yagan and white settlers as a series of cultural misunderstandings leading to his death. Instead, Yagan (re)appeared through a contemporary violent encounter that mimicked his murder in 1833. 
The search for, and repatriation of Yagan's head to the Noongar people began sometime in the early 1950s, finally located and exhumed from the Everton Cemetery in Liverpool, UK in 1997 (National Museum of Australia n.d.). This repatriation triggered a racist and symbolic re-enactment when the head of a memorial statue was removed with an angle grinder. These modern day headhunters attacked the statue, beheading it twice and invoking the power of mimesis to invigorate our modern memorials and monuments with a lie of their own' (Martin 2007, p. 316). Indigenous writer Archie Weller responded to this (post-) colonial violence in Confessions of a Headhunter (Weller and Riley 2000). Weller's film shows two young Indigenous men 'beheading' memorials of white colonial heroes around the country, beginning with Stirling and ending with Cook. It is

a film that speaks about the conflict between Indigenous people or Noongar of the Perth area, and colonial culture. The symbolic violence that is the artefact of an actual war that took place-and as the film suggests - is still taking place, is represented here by the Indigenous characters, who retaliate to the disrespect shown to their ancestor warrior Yagan, an important part of Noongar heritage and culture (Moreton-Robinson 2000).

\section{Yagan}

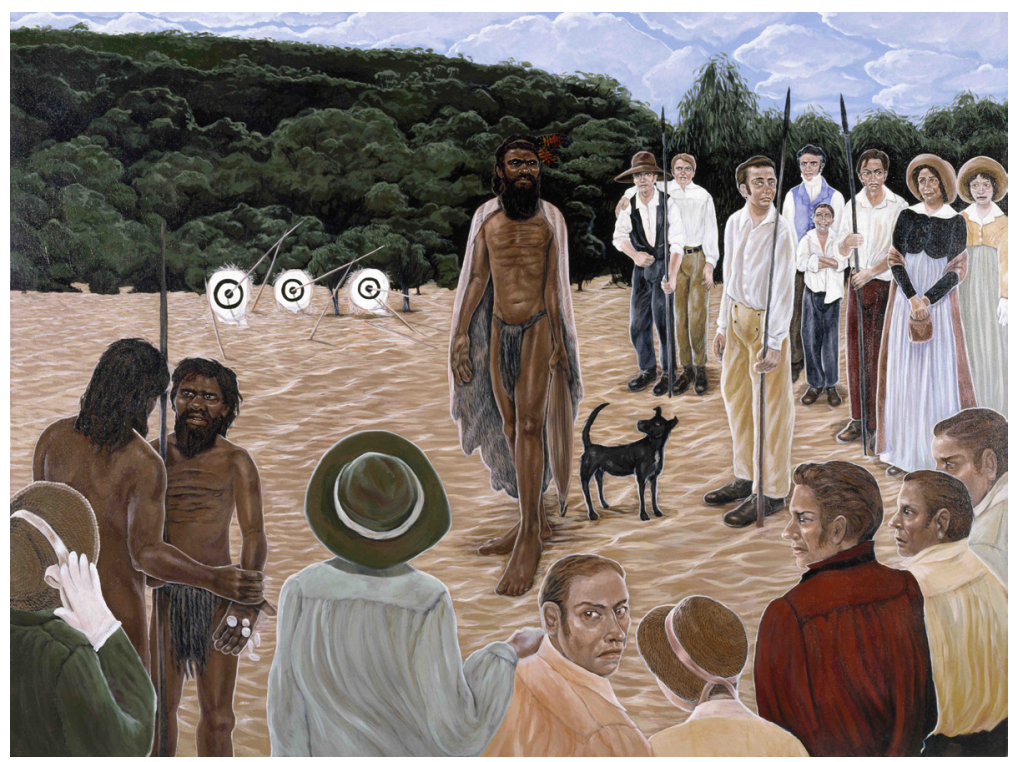

\section{'Yagan', Julie Dowling (2006).}


The visual portrayal of historic moments for mass consumption has been a successful method for producing history and telling stories, standing in for public memory, and is instrumental in constructing cultural knowledge (Edwards 2001, p. 149). In 2006, Julie Dowling's painted image of Yagan, the Indigenous leader, works to reinsert Indigenous presence into the visual records of history. Painted 170 years after his murder, Dowling's painting does not tell us of the violence of Yagan's death, but of the power and impact of his life. While Pitt Morison's painting reinforces an idea of Indigenous absence, Dowling's twentyfirst-century image tells the story of first contact differently, recalibrating Indigenous presence into colonial history (Smith 1998). In this picture, Yagan is taking part in a public competition in a display of strength. Neville Green describes the event that took place on 13 March, 1833: 'The theme of the corroboree was a kangaroo hunt and Yagan, the master of ceremonies, acquitted himself with a grace and dignity that surprised those who had regarded him only as an implacable ruffian' (Green 1984, p. 82).

Julie Dowling writes:

Yagan was an outlaw leader by that stage and he walked into the scene with his small female black and white mutt that he picked up somewhere and trained as a hunting dog.

The swans in the area were at extinction (and they are now because the black swans you see aren't the original ones that lived in Perth) so he was making a statement about his moral will over their invasions with guns etc. He simply joined in the tournament and won every contest ... it started early in the day till late afternoon and by the end of the day everyone knew it was Yagan but they couldn't arrest him because the Noongars outnumbered the non-indigenous by about ten to one ... the rest is that he simply walked through the parting crowd and back up to the hills many $\mathrm{km}$ away ... I guess they wanted to see the character of the 'native' but what they found was a crew of Spartans laconically treating them to a good honest moral display of strength with no violence.

The place where the Perth entertainment centre is located now used to be (and still is by many Noongars today) as a great place for meetings and a good feed of shellfish. This place was where they initially met but because the crowd grew it seems that the tournament took place on the foreshore near where the Narrows Bridge is today.

The oral history goes that when people found out it was Yagan they all were in awe because he was taller than most of them and very handsome.

So I modelled him on some of his known descendants the Wyatt's and Bodney's I grew up with in Belmont and Redcliff not far from Perth (personal communication). 
Killed by William Keats in 1833, Yagan's skin markings were sliced from his body and his head severed and smoked. A young James Keats was rewarded for his brother's successful headhunting, and Robert Dale took this 'trophy' to England to be displayed as a parlour curiosity (Perth Gazette 1834). An etching of Yagan's smoked head is held in the National Library of Australia and this image accompanies his entry in the Australian Dictionary of Biography (Havell 1834). The reproduction of this image shows Yagan as a 'prize' of white colonisation, not the respected and fierce Indigenous leader described in accounts of his life. Hannah McGlade describes the history around Yagan as 'an extremely powerful story: it is a story of invasion, and early contact between two cultures; of colonialism and its racist bloody nature. It is, to the dominant culture a threatening story' (McGlade 1998, p. 252).

Dowling's painting in the state collection at the Art Gallery of Western Australia brings Yagan's story into the colonial conversation next to Mrs Dance. Standing in front of this picture I am relieved. Is that the right word, is it relief? Here is Yagan and over there is Mrs Dance. Yagan is witnessing us, in the present, Mrs Dance and me, we are unsettled, he stands looking at me. I enter into an 'imaginative engagement' (Wilder 2007) with these pictures, starting a conversation between both the pictures and my fellow onlookers, a cacophony of possible histories rush at us, if we sit down here in the gallery we can talk, and think, it is too hot outside. Here we all are in the same space, at the same time, remembering our forgetfulness (Haebich 2011, pp. 1033-1044). Perhaps we should have a break from history, sit down to share a meal and a cool drink in the café.

Dowling writes:

First contact relationships between Aboriginal and non-Aboriginal people in the colonies reveal much about the divide that continues to exist today and this painting is about what we can learn from such engagements (Dowling 2006).

Her work demands us to engage with history now, to bring the past into our present, to think about what to remember. In the gallery, Yagan enlivens Mrs Dance, 'answering back'. Dowling's rendering includes Indigenous onlookers and early settlers, whose diaries and writings have informed her work. 'By using the colonial romantic imagery of Aboriginal people as a tool, I can inform non-Aboriginal people of the denial of Aboriginal culture in current representations of Australian history' (C. Dowling 2006). Pitt Morison's hero, Governor Stirling, is transformed in Dowling's painting into the perplexed onlooker (in the red shirt). Carol Dowling, Julie's sister, writes: 'We reach across generations, trying to understand what had happened to our people, feeling what we have in common with them and where we differ, so that we 
can see who we are and see what we might become' (C. Dowling 2006). In a process that mimics and enchants, Dowling's painting returns an Indigenous past to me, part of a dialogue, a 'disruptive form of encounter' (Rose 2008, p. 157). Yagan stands triumphantly on the hot sand, challenging me, my whiteness, my understanding, returning my gaze. This past is not complete and neatly packaged, disconnected from the present, it is here, in the ongoing conversation of place, in the cool gallery and on the hot sand.

\section{History's Breath}

This is the problem with history, isn't it? If you think you can know it by simply reading it as a discrete entity, an independent body that can be walked around, wholly mapped, wholly disciplined, then you will never feel its breath (Schlunke 2004, p. 167).

Julie Dowling's painting repatriates Yagan and Indigenous presence to the everyday of the twenty-first century, next to a slightly uneasy Mrs Dance, who is losing her grasp on the national narrative. Yagan's story destabilises and unsettles white settler history and a past that is too shameful to tell. In the context of the art gallery, his presence facilitates thinking about perceptions of time, identity and history. The white onlooker and researcher is drawn into the conversation, moral accountability and responsibility. In the comfort of the cultural institution, we look again at the visual representation of these events and the making of history, now displayed in close proximity. The past, our past here returning to the present, a past held in place through storytelling and painting. These pictures demand that we attend to the 'whitefella crises' of 'what to remember and what to forget', questioning what we think we know and how we remember. Here in the gallery, escaping the heat of a Perth summer day and waiting for the sea breeze, we might feel history's breath.

\section{Acknowledgements}

Thank you to Katrina Schlunke for early comments on the ideas in this paper, Prudence Black for her comments, Anna Cole for her editorial responses, the conference and editorial team, Oliver Haag, Vanessa Castejon and Karen Hughes, and to the anonymous reviewers for their thoughtful suggestions to this paper. Importantly, thanks to Julie Dowling for sharing her thoughts and her painting about Yagan. 


\section{References}

Bulbeck, C 2007, 'Aborigines, Memorials and the History of the Frontier', Australian Historical Studies, vol. 24, no. 97, pp. 168-178.

Connerton, P 2008, 'Seven Types of Forgetting', Memory Studies, vol. 1, pp. 59-71.

Cygnet, 1935, The Story of the Birth of Perth: Early days in Western Australia, Swan River Booklets no. 4, Paterson Brokensha, Perth.

Davenport, C, M La Fontaine \& J Carty 2011, 'Yiwarra Kuju, The Canning Stock Route', National Museum of Australia travelling exhibition, Perth Convention Centre, 2-27 November, 2011.

Dowling, C 2006, 'Bal Goort Gootun Gunyuing (Her Heart Has Broken)' in J Dowling, Widi Boornoo (Wild Message). Available at: http://members.iinet. net.au/ artplace/catalogs/WidiBorno.pdf.

Dowling, J 2006, Australian National Indigenous Triennial: Culture Warriors, National Gallery of Australia. Available at: http://nga.gov.au/Exhibition/ NIAT07/Detail.cfm?IRN=144778.

Durack, M 1964, The Courteous Savage: Yagan of the Swan River, Thomas Nelson, Melbourne.

Edwards, E 2001, Raw Histories, Berg, Oxford.

Ferrell, R 2004, The Real Desire, Indra Publishing, Melbourne, pp. 29-46.

Fletcher, 1984, 'The Battle for Pinjarra: A revisionist view', Studies in Western Australian History, vol. 8, pp. 1-6.

Gibson, R 2010, 'The Known World', TEXT, special issue no. 8, 'Creative and Practice-Led Research: Current status, future plans'.

Gooding, J 1989, ‘The Foundation of Perth: George Pitt Morison's persistent image', Studies in Western Australian History, vol. 10, pp. 114-120.

Green, N 1984, Broken Spears: Aborigines and Europeans in the southwest of Australia, Focus Education Services, Perth.

Haebich, A 2011, 'Forgetting Indigenous Histories: Cases from the history of Australia's Stolen Generations', Journal of Social History, vol. 44, no. 4, pp.1033-1044. 
Ngapartji Ngapartji, In Turn, In Turn: Ego-histoire, Europe and Indigenous Australia

Haebich, A 2004, "Clearing the Wheatbelt": Erasing Indigenous presence in the southwest of Western Australia, in A D Moses (ed.), Genocide and Settler Society, Berghahn Books, Oxford, pp. 267-289.

Haebich, A 1988, 'Neville, Auber Octavius (1875-1954)', Australian Dictionary of Biography, National Centre of Biography, The Australian National University. Available at: http://adb.anu.edu.au/biography/neville-auber-octavius-7821/ text13575.

Hage, G 2003, Against Paranoid Nationalism: Searching for hope in a shrinking society, Pluto Press, Annandale, pp.47-66.

Havell, R 1834, 'Yagan', Australian Dictionary of Biography, National Centre of Biography, The Australian National University. Available at http://adb.anu. edu.au/biography/yagan-2826.

Hawke, S \& M Gallagher, M 1989, Noonkanbah: Whose land, whose law, Fremantle Arts Centre Press, Fremantle.

Healy, C 2008, Forgetting Aborigines, UNSW Press, Sydney.

Idle, J 2010, 'Mrs Dance Strikes the First Cut: Visual storytelling and girlhood', Journal of Australian Studies, vol. 34, no. 4, pp. 527-541.

Isaacs, J 2011, Spirit Country: Contemporary Australian Aboriginal art, Hardie Grant, Melbourne.

Martin, D 2007, 'Of Monuments and Masks: Historiography in the time of curiosity's ruin', Postocolonial Studies, vol. 10, no. 3, pp. 311-320.

McGlade, H 1998, 'The Repatriation of Yagan: A story of manufacturing dissent', Law Text Culture, vol. 4, no. 1, pp. 245-255.

Moreton, R n.d., 'Confessions of a Headhunter', curator's notes, Australian Screen, National Film and Screen Archives. Available at: http://aso.gov.au/ titles/shorts/confessions-headhunter/notes/.

Moreton-Robinson, A 2000, 'Talkin' Up to the White Woman: Indigenous women and white feminism', in M Grossman (ed.), Blacklines: Contemporary critical writing by Indigenous Australians, University of Queensland Press, St Lucia, pp. 66-77.

National Museum of Australia n.d., 'Yagan's story'. Available at: http://www. nma.gov.au/exhibitions/first_australians/resistance/yagan.

Nugent, M 2009, Captain Cook Was Here, Cambridge University Press, Melbourne. 
Perth Gazette 1834, 'Yagan's Head', 13 December, 1834. Available at: http:// trove.nla.gov.au/ndp/del/article/641141.

Rose, D B 2008, 'On History, Trees and Ethical Proximity', Postcolonial Studies, vol. 11, no. 2, pp. 157-167.

Rose, D B 2004, Reports From a Wild Country: Ethics for decolonisation, UNSW Press, Sydney.

Rose, D B 1997, 'Dark Times and Excluded Bodies in the Colonisation of Australia', in G Gray \& C Winter (eds), The Resurgence of Racism: Howard, Hanson and the race debate, Department of History Monash University, Melbourne, pp.97-116.

Schlunke, K 2005, Bluff Rock: Autobiography of a massacre, Fremantle Arts Centre Press, Perth.

Schlunke, K 2004, 'Useless History', Cultural Studies Review, vol. 10, no. 2, pp.165-167.

Secomb, L 2002, 'Haunted Community', in M Strysick (ed.), The Politics of Community, The Davies Group, Aurora, pp. 131-150.

Smith, T 1998, 'Visual Regimes of Colonisation: Aboriginal seeing and European vision in Australia', in Nicholas Mirzoeff (ed.), The Visual Culture Reader, Routledge, London and New York, pp. 483-494.

Spivak, G 1989, 'The Intervention Interview', in S Harasym (ed.), The PostColonial Critic: Interviews, strategies, dialogues, Routledge, New York.

Stanner, W E H 1991, 'The Great Australian Silence: Stanner after the dreaming' Boyer Lecture Series, ABC.

Stephen, A 2006, On Looking at Looking: The art and politics of Ian Burn, Miegunyah Press, Melbourne.

Weller, A \& S Riley 2000, Confessions of a Headhunter, Scarlett Pictures. Available at: http://aso.gov.au/titles/shorts/confessions-headhunter/.

Wilder, K 2007, Negotiating Painting's Two Perspectives: A role for the imagination, Image[\&]Narrative, vol. 18. Available at: http://www. imageandnarrative.be/inarchive/thinking_pictures/wilder.htm.

Wright, A 2007, 'AWAYE!', ABC radio. Available at: http://www.abc.net.au/ radionational/programs/awaye/2007-07-28/3669386. 
This text taken from Ngapartji Ngpartji: In turn in turn:

Ego-histoire, Europe and Indigenous Australia

Edited by Vanessa Castejon, Anna Cole, Oliver Haag and Karen Hughes,

published 2014 by ANU Press, The Australian National University, Canberra, Australia. 